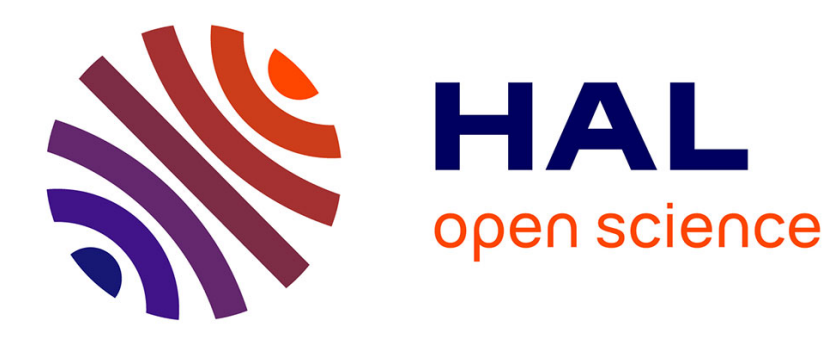

\title{
The Empirical Turn of Literary Studies
}

Alexandre Gefen

\section{To cite this version:}

Alexandre Gefen. The Empirical Turn of Literary Studies. Nicoletta Pireddu. Reframing Critical, Literary, and Cultural Theories, Palgrave Macmillan, Cham, pp.119-135, 2018, 978-3-319-89990-9. hal-01959123

\section{HAL Id: hal-01959123 \\ https://hal.science/hal-01959123}

Submitted on 18 Dec 2018

HAL is a multi-disciplinary open access archive for the deposit and dissemination of scientific research documents, whether they are published or not. The documents may come from teaching and research institutions in France or abroad, or from public or private research centers.
L'archive ouverte pluridisciplinaire HAL, est destinée au dépôt et à la diffusion de documents scientifiques de niveau recherche, publiés ou non, émanant des établissements d'enseignement et de recherche français ou étrangers, des laboratoires publics ou privés. 


\section{The Empirical Turn of Literary Studies}

Alexandre Gefen, CNRS-Université Paris 3 - Sorbonne Nouvelle

By the end of the 20th century, literary theory had acquired the mythified value of a universal explanatory framework, placing theories of the text in original ways at the roots of the tree of knowledges, and turning their academic analysts into the masters of such knowledge. With French Theory, textual and narrative theories, as well as rhetoric and semiology, were used to decoding the most disparate social facts, be it to understand a lover's discourse for Barthes, to deconstruct philosophy through literature for Jacques Derrida, to rethink historical narrative in Hayden White, or to analyze the poetics of science for Fernand Hallyn. Pursuing the linguistic turn that had affected philosophy, literary theory had led textual categories and logics to a universal and hegemonic ambition: everything was language, everything constituted discourse, everything represented a sign. In that respect, literary theory was more than a theory of literature, more than an epistemology or a « critique of critique ». It was, indeed, a "critique of ideology"1 inseparable from an explicitly Foucauldian and secretly Marxist critical social thought, be it in its American culturalist version or in its more directly political French formulation. The critiques erected against this kind of literary theory have been clearly identified, and the cultural war against the cultural studies and their social constructivism centered around sexual and racial issues have resulted in a stagnation of theory, at least in the most prominent U.S. universities. The alliance of formalism and of left-wing ideologies in the service of an identitarian discourse, or the adoption of Derridian deconstruction as an anticapitalist weapon have been the object of fierce criticism, since the debate initiated the $1980 s^{2}$ by Steven Knapp and Walter Benn Michaels' ruthless article « Against theory » which triggered Richard Rorty's and Stanley Fish's counter-attack ${ }^{3}$, down to Daphne Patai and Will H. Corral's Theory's Empire: An Anthology of Dissent (2005). The expressions « posttheory » 
and "after theory» have become commonplace, as also Vincent B. Leitch notes. ${ }^{4}$ The influence of Wittgenstein and of pragmatism, the « anti-foundationalist » and neo-pragmatic tendencies in the United States, and the return to «common sense » commended by Antoine Compagnon in France have demolished the most ideological and globalizing theories. Facing widespread scepticism, the « the claim and the dream of Baconian method » and of " general hermeneutic » $\left(\right.$ Stanley Fish $\left.{ }^{5}\right)$ seems to have waned. What was at stake in Knapp and Michaels was not so much the need for an epistemology of critique, or the different critical methods themselves, but, rather, the ambition of theory to attain interpretive objectivity or to recover an original intentionality ${ }^{6}$ in accord with a unified set of issues, and, obviously, the tendency of those textual theories to function as counterdiscourses.

In this beginning of the 21 st century, these debates broadly related to problems of philosophy of language have largely lost their relevance. Far from these issues, I would like to focus on the emergence of a literary theory that is shaped by the informational, cognitive and computational turn of contemporary science. On the one hand, literary methodologies based upon cognitive sciences propose new powerful descriptions of the literary fact endowed not only with an interpretive function but also with truly explanatory and «foundationalist» values. On the other hand, the approaches deriving from digital humanities propose demonstration methods that render literary theory testable and literary phenomena foreseeable, at the cost of a veritable epistemological rupture. Far from the linguistic models of the previous century, it is hence a new scientificity that is being designed by the deductive models stemming from cognitive sciences and the inductive approaches of digital data analysis.

\section{Literature and Cognitive Sciences}


It is important to measure the magnitude of such a change. To a large extent, the theories of literature that dominated until post-structuralism were literary because they were founded upon the substratum of linguistics or of rhetoric, hence they were endogenous. This does not mean absence of exogenous explanatory theories of literary mechanisms (let's think, for instance, of 19th-century philosophy of history as it survived the 20th century; Foucault's theory of power; or Bourdieu's thought on the notion of distinction), yet those theories still belonged to the humanities and to their own validation criteria. These theories had the descriptive power of structuralism, with a remote mathematical background. They could offer, in some cases, recommendations or prescriptions, especially literary ones, but the biological and physical realities of the phenomena that they evoked remained totally out of reach. In the last two decades, by contrast, cognitive sciences have offered themselves as the allencompassing explanatory paradigm of psychological and even social facts, arousing a blend of fascination and repulsion, and entailing indirect repercussions even beyond their own proposals. Therefore, the interest that in recent years literary theory has demonstrated in reading and, broadly speaking, in the effects of literature cannot be isolated from the cognitivist pretensions of thinking «the neurons of reading », to evoke the title of a famous essay by neuroscientist Stanislas Dehaene. ${ }^{7}$

Neurosciences are a heterogeneous ensemble in which we can distinguish three major directions--neurological analysis of cognitive processes, experimental psychology and cognitive anthropology--, which, in their turn, have opened paramount fields in literature, such as cognitive poetics, literary psychology and literary evolutionism. Relying heavily on cognitive linguistics, different branches of cognitive poetics developed out of Lakoff and Johnson's study Metaphors We Live By (1980), and Reuven Tsur's works on the perception of poetry. Starting from cognitive stylistics and rhetoric, they were then enriched by cognitivist 
narratology, which works, for instance, on the notion of suspense ${ }^{8}$ o reexamine the theory of fiction from the new approach of possible-world theory founded upon deixis.

Based upon a psycholinguistics of attention to and on the foregrounding of expressive traits or figures, the analysis of the so-called prototypicality of structures, or a reflexion on the mental phenomena enabled by metaphorization, cognitive poetics, redefines literature as a defamiliarization and manipulation of our structures of attention. ${ }^{9}$ This theory purports, for instance, to explain through cognitive constraints certain traits of versification (like the caesura separating the two hemistichs of an alexandrine verse in classical French poetry $)^{10}$ but it is hence much more ambitious than the simple analysis of the way in which the human brain analyzes simple information like symbols. Il also tackles complex phenomena, proposing in particular to rethink literary genres and categorizations not as structural systems but as byproducts of cognitive prototypes (concentric structures ${ }^{11}$ ) brought together by family resemblances and legitimizing themselves through Gestalt psychology ${ }^{12}$. The notions of deictic field and of deictic shift theory are particularly useful to understand our immersion situation in a narrative. Our immersion takes into account both elements that push us into a story and those that refer (pull) us towards the real world by following the strategies of localization of contexts that we bring to the process through our involvement into (the) fiction. ${ }^{13}$ Imagination, which enables access to fiction, produces deictic displacements, and cognitive psychology attempts to model the reader's subjective experience in his/her movements and encounters with the fictional subjectivities of the narrator and the characters. This is a truly new task that had pertained to literary theory only through phenomenology and that it is now thought in terms of information processing. Yet it has to be acknowledged that one of the immediate horizons of a theory — that of the cognitive displacement of deixis - is clearly backed by a will to cybernetic modelisation consisting in making a computer program understand the narrative situation. ${ }^{14}$ From the conversion of cultural facts into measurable 
mental processes and then into quantifiable data, the process is continuous. The epistemology of cognitive sciences is certainly closer to that of computational sciences than of traditional humanities.

It should be noted that cognitivist poetics rely on the idea coming from neurosciences that language is not a specific module in order to claim that it is necessary to think the relation of linguistic phenomena to the body and society, ${ }^{15}$ rejecting at once the body/mind distinction and the nature/culture opposition. As it decenters the theory of the question of the text or of its author, in favor of that of the reader, literary cognitivism is empirical and naturalizing, in the double meaning: it founds the functioning of literature upon natural facts and trivializes literature by conceiving of it as a mental activity like any other rather than an exceptional regime. In so doing/Therefore, cognitive poetics reintegrates literature into ordinary human activities: "Cognitive poetics, too, sees literature not just as a matter for the happy few, but as a specific form of everyday human experience and especially cognition that is grounded in our general cognitive capacities for making sense of the world."16 On these premises, literary history is no longer anything else than the exploration of common mental dispositions: Reuven Tsur claims that « cognitive processes shape and constrain cultural and literary forms [...] the infinite variety of cultural forms may arise in cultural programs constrained and shaped by the same cognitive capacities"17 against the idea of an autonomy of the cultural sphere and its own historicity. This, in passing, also entails the reconceptualization of the comparatist, because the intercultural echoes are rethought as the activation of the same dispositions across different contexts. This project reemerges in cognitive aesthetics, or neuroaesthetics, which tends to oppose an empirical to a philosophical approach to art, and replaces conceptual categories in aesthetic judgment with aesthetic perceptions based upon feelings of immediate appreciation, pleasure and displeasure. If « les résultats de l'imagerie cérébrale donnent une impression de profondeur explicative, ils servent surtout à soutenir un 
désir de causalité ${ }^{18}$ [the results of cerebral imagery give an impression of explanatory depth, they are above all useful to support a desire for causality], with the paramount epistemological benefit represented by the dream of reintegrating the reading body into literary studies, as Fernando Vidal observes, against constructivism and cultural studies, as much as against an intellectualist approach.

Properly neuroscientific experiences, like those consisting in observing brain activity through imaging during fictional immersion, are very rare ${ }^{19}$ but the literary cognitivist aims at a new scientificity precisely because those experiences do away with the question of interpretation in favor of a reflexion on information, and because they are more interested in the process than in the content. The ambition is, indeed, to propose a systematized study of literature conceived as observable mental reality: «[cognitive poetics] offers a means of describing and delineating different types of knowledge and belief in a systematic way" 20 standing up against the subjectivity of culturalist analyses and of their allegedly questionable and costly:

Moreover, the standard academic practice of producing yet another interpretation of a text from the canon, or, in more recent years, from outside the canon, has been challenged by the taxpayer, who wants better justification for the spending of their money than an academic's sheer individual interest in a particular text. And this justification, too, is what cognitive poetics promises to offer. ${ }^{21}$

Their premises are indeed truly scientific and their results falsifiable. ${ }^{22}$ To be sure, as cognitivists who reflect in epistemological terms observe, this search for scientificity can only be partially attained: “Although CL [cognitive linguistic] is non-idealist, anti-Cartesian, and although many cognitive linguists strive for empirically falsifiable hypotheses and empirical control, the paradigm does not simply reduce the mental realm to deterministic predictability (Lakoff 1987)." ${ }^{23}$ Yet this «indirect empiricism» is meant to be a decisive rupture that 
timidly opens the door to testability, because even if most findings of cognitive poetics draw from the phenomenology of first-person experiences created by cognitive linguistics, literary cognitivists attempt to propose a controlled vocabulary, to rationalize the results of their propositions, to propose inductive reasoning founded upon empirical results and falsifiable hypotheses.

\section{The Epistemological Naturalization of Literary Darwinism}

Strongly criticized in France, in particular by Alain Ehrenberg, for its ambition to replace human sciences, ${ }^{24}$ descriptive cognitivism is completed by a diachronic cognitivism-evolutionist anthropology or cognitive evolutionism--, which aims to analyze cognition at large within a Darwinian framework (natural selection of attitudes and behaviors for the survival and expansion of our species). Its gist, then, is to interrogate not so much the nature of cognitive processes, their mechanisms and cerebral anchoring points, as their causes. Starting from the idea that all human facts, including those of imagination/the imaginary ones, are included in an evolutionary process, the evolutionist conception of aesthetic mechanisms implies discarding metaphysical, sociological, economic, formal, psychological (in a nonevolutionist sense) interpretations, and investigate in what ways aesthetic representations illustrate, exemplify or model the interplay of «hard-wired $»^{25}$ biological forces: survival, reproduction and expansion of the species, competition and cooperation among individuals, families and communities, parenthood, social affiliation, the efforts to acquire resources and influence, domination, aggression, and, ultimately, the need for imagination. ${ }^{26}$ This kind of reflection entails the question of value and challenges the social constructivism informing cultural studies : cognitivists claim that the depth and efficacy of literary works derive from their ability to stage those implacable logics that we do our outmost to forget. To think with evolutionist psychology means also to ask in what terms the production of aesthetic objects 
contributes to shaping the nature of individuals as species and their evolution - man, claims Jonathan Gottschall, a leading figure of this emerging discipline, is a storytelling anima ${ }^{27}-$, be it to explain aesthetic aptitudes as a parasitical biological competence, or as an advanced ability to adapt to an environment, or again, as the equivalent of the mechanisms of optimisation in the choice of partners for sexual reproduction sexuée-for instance in JeanMarie Schaeffer. ${ }^{28}$

Indeed, cognitive evolutionism draws at once from philosophical naturalism and scientific positivism: the ultimate substratum of mental facts is physical, natural, and its ultimate deterministic elements are genetic. The theoretical anchoring for the understanding of our knowledge, its foundation, has to be that of human cognition, as a natural phenomenon finally explainable by the sciences, without recurring to external metaphysical or linguistic models. We are in the framework of what Quine defines as «naturalized epistemology», which is entitled to employ « the resources of natural sciences ». ${ }^{29}$ In this total Spinozism that evokes a form of critical materialism ${ }^{30}$ (in some ways, the equivalent of post-war Marxism for our generation), the only substratum of mental facts is strictly biological, and cerebral evolutions are determined by evolutionary mechanisms enriched by elements from Mendel's theory: aleatory individual variation, environmental pression, genetic selection and transmission of optimal adaptive characteristics. Here, consciousness, religion, as well as literature are products of neural evolution governed by the need to master a complex and dynamic human environment (unlike instinctive behavior or simple adaptation to a fixed and repetitive environment, ascribed to Homo sapiens): what characterizes man as species are cognitive fluidity and neural plasticity. ${ }^{31}$

The consequences of this movement of « naturalization of the human being $»^{32}$ are remarkable from the epistemological point of view: we find ourselves in a psychological framework considered from a non-psychological perspective, ${ }^{33}$ that is, an anti-intentionalist, 
anti-mentalist psychology that does not require to « interpret » private expressions in an allegedly abstract «mental language » with its own logic, but simply to classify empirical facts according to a deductive scientific logic. If we refer back to Wilhelm Dilthey's opposition between natural sciences (Naturwissenschaften) - which generate explanations, or better, forecasts, with the aide of experimental demonstrations or mathematizable reasoning--, and human sciences (Geisteswissenschaften) - producers of understanding --, the evolutionist psychology of literature aspires to be reintegrated into the sciences in general and to produce not so much interpretations as explanations of aesthetic facts. Psychology of art is expected to be founded upon empirical observation, if not on experimentation, and to refrain from any endogenous discourse. Certain hard-core theoreticians like Harold Fromm ${ }^{34}$ are moreover close to the so-called « eliminative materialism » represented in particular by Daniel Dennett - who relates mental facts, including qualia (i.e. subjective effects of our sensations and experiences, morality or religion) to a physiological substratum out of the reach of common sense - and Richard Dawkins - the inventor of the theory of "memes ", that is, of a conception of artistic facts and of culture in general subject to the laws of natural selection. Without going that far, "sociobiological» thought (to retrieve a concept that is frequently employed by the « literary Darwinians $»^{35}$ ) tends to refute interpretation (at least internalising interpretation) -- the speculation on the particular and individual value of works or on the author's personality-, endorsing, instead, quantitative logic or mecanisms of very long duration that provide anthropological explanations of literary forms and works. Just as they try to avoid what for the Wittgensteinians was the illusion of interiority, sociobiological thinkers intend to elude what Quine referred to as « the myth of interpretation» and the idea that signification is part of a discourse that transcends the data we possess to talk about language. By contrast, they reinscribe textual representations devoid of mental substance and of any specific mechanism within natural behavioral determinism. ${ }^{36}$ Another consequence of 
this epistemological position is that, just as literature loses its distinctiveness by being deprived of ontological or even functional autonomy, no formal logic or historicity specific to symbolic productions subsists. There is no more reason to circumscribe an « empire within an empire ». Cognitive evolutionism belongs to the general paradigm that French narrative theorist Jean-Marie Schaeffer, in his eponymous book, qualifies as « the end of the human exception ». It consists in refusing any anthropocentric, teleological or essentialist conception of the human being, ${ }^{37}$ to examine the alleged « humanity » « à la lumière des contraintes qui la régissent comme espèce biologique ${ }^{38}$ » [in light of the constraints that support it as a biological species]. It must be observed that, for Schaeffer as well as for all theoreticians of evolutionism, there is no opposition between cultural and natural order, because culture is a « natural» attribute of the human species. On the contrary, it is necessary to admit the existence and the significance of interactions between biological and cultural dispositions-the so-called génético-cultural coevolution - or, again, between collective resources and constraints, on the one hand, and particular individual dispositions on the other. ${ }^{39}$

Like the cognitivists, the Darwinians justify their approach by a certain failure of human sciences to cope with the scientific demands that they contend to address. They attempt to overcome the aporias of a literary analysis based upon linguistic, cultural or psychoanalytic models, and its crippling inability to become a tool for empirical forecast, despite the structuralist games with the blanks the Marxist literary teleologies. The idea of a methodological failure of traditional humanities refusing experimentation leads Gottschall to talk about «new humanities » benefiting from the contribution of life sciences to propose empirical analyses that have generated virulent reactions. ${ }^{40}$

\section{Digital Humanities and Inductive Approaches}


To this scientistic project, evolutionist research adds an empirical attention to masses of facts. For Jonathan Gottschall, literature must be considered a set of quantitative data on the human species that entail verifiable consequences, insofar as the Darwinian approach « feature[s] literary hypotheses that make testable predictions about empirical reality. ${ }^{41}$ The leap of the interpretive order towards the explanatory one goes hand in hand with a leap from the qualitative towards the quantitative. This project hence joins the approaches founded upon big data in the world of digital humanities. The amount of empirically available data is so important that its quantitative examination can allegedly compensate for any theory, proposing us to shift from a deductive method to inductive ones.

We should not, indeed, underestimate, either, the epistemological leap promised by digital humanities as they propose quantitative options to test hypotheses, making literary research falsifiable, and a passage from the descriptive order (measurement and classification) to causal explanations, by resorting to inferences via regression analysis that render the traditional deductive methods obsolete. By transforming a text or a corpus of texts into data, we subject it to a wide array of measuring instruments. The methods of digital humanities offer a « distant reading », to refer to Franco Moretti's famous concept. ${ }^{42}$ This « textometry » ranges from simple frequency or colocations analysis to more complex measurements of syntactic or semantic structures and advanced machine interpretations like topic modeling ${ }^{43}$. I do not intend to discuss the relative pertinence of these tools--some of them direct or indirect evidentiary forms which vary according to whether one is looking for semantic phenomena with clear textual echoes - presence of an author, reference fields - or for the detection by stochastic analysis of silent paradigm shifts which would be individually drowned out in the noise of frequency analysis. What matters is to see to what extent they modify our traditional approach to the production of evidences and the testing of hypothesis in literary studies. With the capability to "operationalize, $»^{44}$ that is, to verify theoretical or historical hypotheses 
transforming them into quantifiable operations, the propositions of human sciences become verifiable. The masses of data into which cultural history is transcribed allows the critic to verify hypotheses formulated by erudition but otherwise difficult to establish because they are founded upon a global knowledge, a memory of the works, an intuitive synthesis that are arduous to objectivize and hence eventually to refute. Behind the possibility of aligning human sciences with other sciences,${ }^{45}$ there are both institutional and scientific questions at stake - the visibility and the seriousness of the humanities. The unquestionable paradox is that the most elaborate and mathematical tools - like those of distributional semantics, for instance, a method that infers the meaning of a word from its statistical context -, are complex to the point of being accessible only to a handful of researchers, and involve a number of operations of intermediate calculations that run into billions. Emerging domains like the quantitative history of ideas or quantitative formalism confront us with the opacity of digital black boxes, even though the ability to capture and pertinently represent massive facts imposes a field intuition and an old-style knowledge of corpora indispensable for the modeling and interpretation of data.

Beyond the temptation of a new positivism, this mathematization of the proof has additional effects. It gets us accustomed to unprecedented forms of representations because the distant reading of corpora set up as big data through charts and graphs offers a specific form of knowledge in which regularities stand out in a strongly pedagogical way and minority phenomena can be visually detected, very differently from the way in which an old-fashioned erudite scholar used to notice and bring to the foreground an unknown literary trend or a neglected author. Probably other deep epistemological evolutions of the humanities are emerging on the horizon. We can sense that an empirical use of digital humanities could replace its theoretical usage as a tool to verify abstract hypotheses. One of the most disturbing issues raised in the last few years by the latest developments of artificial intelligence in its 
alliance with the remarkable amounts of information of the big data, would be, indeed, to avoid theory to the advantage of a machine learning capable of drawing, by induction, general laws or in any case regularities, empiricist perspectives that would render theoretical propositions obsolete and would even foster literary forecasts, as this is the direction for which machine learning is made, turning cultural history into a nomothetic science-hence, for instance, the ability to predict the success of a best-seller. This is what Jodie Archer (editor) and Matthew L. Jockers (a specialist in digital humanities) propose in The Bestseller Code: Anatomy of the Blockbuster Novel (2016), where they assert their ability to predict the success of a novel before publication by analyzing its content, according to a multifactorial model of machine reading. After advanced statistical methods and the emergence of a graphic knowledge that extended the historical work in different ways, potentially objectifying it, this perspective would transform cultural knowledge even more radically, reducing it to a skillful strategy to launch a machine on a track and interpret the results without resorting to any internal representation of language or literature to draw laws by induction and make predictions. To be sure, we can remain sceptical and remark that the machine only works with data that it receives, hence this kind of approach is deeply dependent upon interpretive choices and theorical frameworks. The fact subsists, however, that artificial intelligence proposes epistemologically disruptive methods capable of profoundly modifying the modalities of demonstration and the very nature of literary knowledge.

\section{The normalization of literary knowledge}

In the empirical turn of contemporary literary studies two distinct phenomena overlap: the decline of linguistic theory has led to pragmatic and empirical field approaches (which have the criticism of the intellectual left, attached to the socially progressive impact of theories ${ }^{46}$ ). Since the outset of the 21 st century, the emergence of electic approaches and a 
methodological individualism have put an end to the preceding theoretical holism. Literary theory and history have become hybrid. Case studies have become more important than analysis of models and the reflexion on narratives more important than that of structures. This movement has been reinforced by a new scientism mainly represented by cognitive sciences that reintegrate literature into the order of ordinary mental facts dependent on brain function and justifying explanations. Evolutionist explanatory models have completed this new global framework of analysis of the literary fact. At the same time, the approaches founded upon data produced by digital humanities have also purported to render literary studies scientific, that is, falsifiable. Even better, the inflation generated by the data-ification of the world proposes inductive working methods that promise to eliminate abstract, exogenous laws to the advantage of quantitaive analysis supported by statistics and artificial intelligence. Not only is literature no longer a universal critical theory of the world or a supreme interpretive matrix, but it does not even have a methodology of its own, as the latter belongs by now to cognitive sciences or data-sciences.

We can see the gain of this normalization of literary knowledge, which is at once its naturalization and its mathematization, namely, the possibility of reintegrating common knowledge and to be recognized as a scientific discipline. What remains to be seen is whether, for research strongly marked by a critical tradition in Europe and by cultural studies in the USA, this new status ascribed to literature (i.e. that of providing a window on brain function and data on the human condition) will manage to compensate for the loss of the aura and of prestige of literary studies, which are incredibly trivialized in the cognitive field. The emergence of scientifically-informed new approaches that treat literature as a fundamental and enlightening cultural fact but not an atypical one can lead to a disciplinary retrenchment as much as to the pacific adoption of new interdisciplinary literary sciences and to the 
discovery of original ways of playing a role in the academic and social field. It is our responsibility to take up this challenge.

\section{Works Cited}

Compagnon, Antoine. Le Démon de la théorie. Paris: Seuil, 1998.

Fish, Stanley. “Consequences.” Critical Inquiry 11, no. 3 (Mar., 1985): 433-458.

Knapp, Stephen and Walter Benn Michaels. « Against Theory », Critical Inquiry, Vol. 8, No. 4 (Summer) 1982: 723-742.

Mitchell, W. J. T. Against Theory: Literary Studies and the New Pragmatism. Chicago: U of Chicago P, 1984.

Rorty, Richard. "Philosophy without Principles," Critical Inquiry 11, no. 3 (Mar), 1985: 459465.

Leitch, Vincent B. Literary Criticism in the 21st Century. London: Bloomsbury, 2014.

Dehaene, Stanislas. Les Neurones de la lecture, Paris: Odile Jacob, 2007.

Baroni, Raphael. La Tension narrative: suspense, curiosité et surprise. Paris: Seuil, 2007.

Stockwell, Peter. Cognitive Poetics: An Introduction. London: Routledge, 2002.

Tsur, Reuven. "Some Cognitive Foundations of 'Cultural Programs',” Poetics Today 23 (1), 2000.

Duchan, Judith F., Gail A. Bruder and Lynne E. Hewitt eds. Deixis in Narrative: A Cognitive Science Perspective. Hillsdale, NJ: Lawrence Erlbaum, 1995.

Shapiro, Stuart C. and William J. Rapaport, “An Introduction to a Computational Reader of Narratives.” In Duchan, J.F., Bruder, G.A., Hewitt, L.E. eds. Deixis in Narrative. Hillsdale, NJ: Erlbaum, 1995: 79-105.

Vandaele, Jeroen and Geert Brône eds. Cognitive Poetics: Goals, Gains and Gaps. Berlin and New York: Mouton de Gruyter, 2009. 
Gavins, Joanna and Gerard Steen eds. Cognitive Poetics in Practice. London: Routledge, 2003.

Vidal, Fernando. « La neuroesthétique, un esthétisme scientiste », Revue d'Histoire des Sciences Humaines, vol. 25, no 2, 2011: 239-264.

Metz-Lutz, Marie-Noëlle, Yannick Bressan, Nathalie Heider and Hélène Otzenberger "What physiological changes and cerebral traces tell us about adhesion to fiction during theater-watching?," Frontiers in Human Neuroscience, 4, 2010.

Ehrenberg, Alain. « Sciences sociales, pas cognitives ,» Libération, 23 septembre 2008. Web. http://www.liberation.fr/tribune/2008/09/23/sciences-sociales-pas-cognitives_14359. [last accessed December 26, 2017].

D. T. Max’s expression in his « The Literary Darwinists », The New York Times Magazine, 6 novembre 2005 . Web. http://www.nytimes.com/2005/11/06/magazine/06darwin.html.

Carroll, Joseph. Reading Human Nature: Literary Darwinism in Theory and Practice. Albany: SUNY Press, 2011.

Gottschall, Jonathan. The Storytelling Animal: How Stories Makes Us Human. New York: Houghton Mifflin Harcourt, 2012.

Schaeffer, Jean-Marie. Théorie des signaux coûteux, esthétique et art. Présentation de Suzanne Foisy. Rimouski (Québec): Tangence éditeur, 2009.

Quine, W.V. «Epistemology naturalized, » Ontological Relativity. New York: Columbia U P, 1969.

. Guerin, Wilfred L, Earle Labor, Lee Morgan, Jeanne C. Reesman, John R. Willingham. A Handbook of Critical Approaches to Literature, 6e éd. Oxford and New York: Oxford U P, 2010. 
. Mithen, Steve J. The Prehistory of the Mind: A Search for the Origins of Art, Religion, and Science. London: Thames and Hudson, 1996.

Lageira, Jacinto. « Artialisation », in Pouivet, Roger and Jacques Morizot eds., Dictionnaire de philosophie esthétique, 2nd ed. Paris: Armand Colin, 2012: 49-50.

Laugier, Sandra. L'Apprentissage de l'obvie: l'anthropologie logique de Quine. Paris: J. Vrin, 1992.

Laugier, Sandra. Wittgenstein, le mythe de l'inexpressivité. Paris: J. Vrin, 2010.

Fromm, Harold. The Nature of Being Human: From Environmentalism to Consciousness. Baltimore: Johns Hopkins U P, 2009.

Schaeffer, Jean-Marie. La Fin de l'exception humaine. Paris: Gallimard, 2007.

Tallis, Raymond. « Neurotrash. Humans Are Special, » Prospect. Web. http://www.prospectmagazine.co.uk/magazine/neurotrash-brain-chemistry-biologismneurones-darwin/. [last accessed December 26, 2017]

Gottschall, Jonathan. Literature, Science, and a New Humanities. New York and London: Palgrave Macmillan, 2008.

Moretti, Franco. Graphs, Maps, Trees: Abstract Models for a Literary History. London and New York: Verso, 2005.

Moretti, Franco.« Literature, Measured, » Literary Lab Pamphlets,12, April 2016. Web. https://itlab.stanford.edu/LiteraryLabPamphlet12.pdf. [last accessed December 26, 2017]

Cusset François and Frédéric Lordon, “Débat: Le Refus de la théorie.” Web. http://tedoctorants.blogspot.fr/2013/09/debat-le-refus-de-la-theorie-23e-salon.html. [last accessed December 26, 2017].

\section{Notes}


${ }^{1}$ Antoine Compagnon, Le Démon de la théorie, Paris : Seuil, 1998, p. 13.

${ }^{2}$ Knapp and Benn Michaels's epistemological point of view aimed at rejecting all difference between intention and signification, hence between theory and practice. See «Against Theory », Critical Inquiry, Vol. 8, No. 4, Summer, 1982. See also W. J. T. Mitchell, Against Theory: Literary Studies and the New Pragmatism, Chicago : The University of Chicago University Press, 1984, p. 3 and $s q$.

${ }^{3}$ See Richard Rorty, "Philosophy without Principles", Critical Inquiry 11, no. 3 (Mar., 1985): 459-465 and Stanley Fish, "Consequences”, Critical Inquiry 11, no. 3 (Mar., 1985): 433-458, reprinted in W. J. T. Mitchell, Against Theory: Literary Studies and the New Pragmatism.

${ }^{4}$ Vincent B. Leitch, Literary Criticism in the 21st Century, London : Bloomsbury, 2014, p. 16.

${ }^{5}$ Stanley Fish, "Consequences" in W. J. T. Mitchell, Against Theory: Literary Studies and the New Pragmatism, op. cit., p. 110 and p. 121 and W. J. T. Mitchell's comments, ibid., p. 4.

${ }^{6}$ See S. Fish, “Consequences”, op. cit., p. 106.

${ }^{7}$ See Stanislas Dehaene, Les Neurones de la lecture, Paris : Odile Jacob, 2007.

${ }^{8}$ See Raphael Baroni, La Tension narrative : suspense, curiosité et surprise, Paris : Seuil, 2007.

${ }^{9}$ Peter Stockwell, Cognitive Poetics: An Introduction, London : Routledge, p. 19 and ff.

10 Reuven Tsur, "Some Cognitive Foundations of "Cultural Programs",", Poetics Today (2002), 23 (1), p. 68.

${ }^{11}$ Peter Stockwell, Cognitive Poetics: An Introduction, op. cit., p. 29 and ff.

${ }^{12}$ Gestalt psychology ("psychology of forms") offers to describe the cognitive processes of perceptions as global and systematic constructions of the mind.

${ }^{13}$ See Judith F. Duchan, Gail A. Bruder and Lynne E. Hewitt (éd.), Deixis in Narrative: A Cognitive Science Perspective, Hillsdale, NJ: Lawrence Erlbaum, 1995. 
${ }^{14}$ See Stuart C. Shapiro and William J. Rapaport, "An Introduction to a Computational Reader of Narratives, ibid., p. 79-107.

15 See, for instance, Jeroen Vandaele and Geert Brône eds. Cognitive Poetics Goals, Gains and Gaps, Berlin and New York: Mouton de Gruyter, p. 6 and sq.

16 Joanna Gavins and Gerard Steen (éd.), Cognitive Poetics in Practice, London : Routledge, 203, p. 1.

${ }^{17}$ Reuven Tsur, "Some Cognitive Foundations of "Cultural Programs",", op. cit., p. 64.

${ }^{18}$ See Fernando Vidal, «La neuroesthétique, un esthétisme scientiste », Revue d'Histoire des Sciences Humaines, vol. 25, nº 2, 2011, p. 239-264.

${ }^{19}$ See, for instance, Marie-Noëlle Metz-Lutz, Yannick Bressan, Nathalie Heider and Hélène Otzenberger "What physiological changes and cerebral traces tell us about adhesion to fiction during theater-watching?," Frontiers in Human Neuroscience, 2010; 4: 59.

${ }^{20}$ Peter Stockwell, Cognitive Poetics: An Introduction, op. cit., p. 4.

${ }^{21}$ Joanna Gavins and Gerard Steen (éd.), Cognitive Poetics in Practice, op. cit., p. 2.

${ }^{22}$ See for instance Peter Stockwell, Cognitive Poetics: An Introduction, op. cit., p. 59.

${ }^{23}$ Jeroen Vandaele et Geert Brône (éd.), Cognitive Poetics Goals, Gains and Gaps, op. cit., p. 7.

${ }^{24}$ See Alain Ehrenberg, « Sciences sociales, pas cognitives », Libération, 23 septembre 2008, Web. http://www.liberation.fr/tribune/2008/09/23/sciences-sociales-pas-cognitives_14359.

${ }^{25}$ I am adopting D. T. Max’s expression in his « The Literary Darwinists », The New York Times Magazine, 6 novembre 2005. Web.

http://www.nytimes.com/2005/11/06/magazine/06darwin.html.

${ }^{26}$ Joseph Carroll, « An Evolutionary Paradigm for Literary Studies », in Reading Human Nature: Literary Darwinism in Theory and Practice, Albany (N.Y.) : Suny Press, 2011, p. 1354, p. 30. 
${ }^{27}$ Jonathan Gottschall, The Storytelling Animal: How Stories Makes Us Human, New York : Houghton Mifflin Harcourt, 2012.

28 Jean-Marie Schaeffer, Théorie des signaux coûteux, esthétique et art, présentation de Suzanne Foisy, Rimouski (Québec) : Tangence éditeur, 2009.

${ }^{29}$ W.V. Quine « Epistemology naturalized » in Ontological Relativity, New York : Columbia University Press, 1969, p. 82 et p. 84.

${ }^{30}$ Wilfred L. Guerin, Earle Labor, Lee Morgan, Jeanne C. Reesman, John R. Willingham, A Handbook of Critical Approaches to Literature, 6 éd., Oxford and New York : Oxford University Press, 2010, p. 146 sqq.

${ }^{31}$ Steve J. Mithen, The Prehistory of the Mind: A Search for the Origins of Art, Religion, and Science, London : Thames and Hudson, 1996.

$32 C f$. Jacinto Lageira, «Artialisation », in Roger Pouivet and Jacques Morizot (dir.), Dictionnaire de philosophie esthétique, $2^{\mathrm{e}}$ éd., Paris : Armand Colin, 2012, p. 49-50, cit. p. 50 .

${ }^{33}$ Sandra Laugier, Wittgenstein, le mythe de l'inexpressivité, Paris : J. Vrin, 2010, p. 24.

${ }^{34}$ Harold Fromm, The Nature of Being Human: From Environmentalism to Consciousness, Baltimore : Johns Hopkins University Press, 2009.

35 Expression coined by the American biologist Edward O. Wilson. See D. T. Max, « The Literary Darwinists », cited.

36 Voir Sandra Laugier, L'Apprentissage de l'obvie: l'anthropologie logique de Quine, Paris : J. Vrin, 1992, p. 93 sqq.

37 Jean-Marie Schaeffer, La Fin de l'exception humaine, Paris : Gallimard, 2007, p. 185-200. 38 Ibid., p. 201.

39 Ibid., p. 249. 
40 See for instance Raymond Tallis, « Neurotrash. Humans Are Special», Prospect. Web. http://www.prospectmagazine.co.uk/magazine/neurotrash-brain-chemistry-biologismneurones-darwin/.

41 Jonathan Gottschall, Literature, Science, and a New Humanities, New York : Palgrave Macmillan, 2008, p. 64.

${ }^{42}$ See Franco Moretti, Graphs, Maps, Trees: Abstract Models for a Literary History, London and New York : Verso, 2005.

${ }^{43}$ On this technique see http://mimno.infosci.cornell.edu/topics.html.

${ }^{44}$ See Franco Moretti, « Literature, Measured », Literary Lab Pamphlets, n ${ }^{\circ}$, avril 2016. Web. https://itlab.stanford.edu/LiteraryLabPamphlet12.pdf.

${ }^{45}$ This is a recurrent ambition that can be observed at every change of scientific paradigm. We can certainly find it in the positivist thought of literary history or in the linguistic turn and the horizon constituted by formal linguistics.

${ }^{46}$ See the seminar organized by François Cusset and Frédéric Lordon, two major representatives of left-wing French theory. Web. http://tedoctorants.blogspot.fr/2013/09/debat-le-refus-de-la-theorie-23e-salon.html. 